\title{
Design, synthesis and determination of physical and chemical characteristics of glycoconjugates as model for oligosaccharide vaccines against vibrio cholerae
}

\author{
Aleksandra Grozdanova*, Ana Poceva, Katerina Milenkova, Ljubica Suturkova \\ Institute of Pharmaceutical Chemistry, Department of Immunology and Immunochemistry Faculty of Pharmacy, \\ University "Ss. Cyril and Methodius", Skopje, Republic of Macedonia
}

Received March 2003; accepted August 2003

\begin{abstract}
Cholera is toxin-mediated enteroinfection, with epidemic character and there are approximately 120000 death cases per year worldwide. Protection against cholera has not been accomplished due to deficiencies in the licensed vaccines. Serum vibriocidal activity mediated by LPS antibodies is the only immune segment correlated with the resistance of cholera.

On the basis of literature data (Robbins JB, 1990; Ogawa Y, 1996) we synthesized glucoconjugates, composed of detoxified LPS from Vibrio cholerae and protein carriers. Conjugate vaccines were prepared by binding acetic acid and hydrazine-treated lipopolysaccharide (LPS) from Vibrio cholerae O1, serotype Inaba, to cholera toxin B-subunit (CT-B) and bovine serum albumin (cBSA). Adipic acid dihydrazide was used for derivatization of oligosaccharides and 1-ethyl-3-(3-dimethylaminopropyl) carbodiimide (EDC) as conjugating agent. SDS-PAGE, glycoprotein detection and TLC dot-blot were used for physical and chemical analysis of the prepared four types of conjugates. Safe level of endotoxins, measured by LAL assay was detected in all conjugates. The synthesized conjugates can be used for monitoring immunization schemes on experimental animals. It is to be expected that conjugated vaccines are safe and efficient and that will have high immunogenic and T-dependant characteristics with long immune protection against cholera.
\end{abstract}

Key words: vaccines, glycoconjugates, Vibrio cholerae, LPS, cholera toxin

\section{Introduction}

Cholera is caused by Vibrio cholerae strains belonging to two serogroups, $\mathrm{O} 1$ and O139, based on their LPS structure. Serogroup O1, which is responsible for the seventh cholera pandemic, is divided into three serotypes, Inaba, Ogawa and Hikojima (1). In the year 2002, World Health Organization (WHO) estimated that over 220,000 people were stricken with cholera each year. Natural infection and currently available vaccines offer incomplete protection of relatively short duration. The long-term control of cholera depends on good personal hygiene, uncontaminated water supply and appropriate sewage disposal. However, the improvement of hygiene is a distant goal for many countries. Thus, the availability of an effective cholera vaccine

E-mail: alpa@baba.ff.ukim.edu.mk

Phone ++389 2 126032; fax: ++389 2123054 is important for the prevention of cholera in these countries. The only vaccines recommended from WHO for massive immunization of population in cholera epidemic regions is $\mathrm{WC} / \mathrm{rBS}$ per oral cell vaccines. The vaccines CVD 103-HgR is used mainly for immunization of people who travel in cholera epidemic regions.

A conjugate vaccine composed of the detoxified LPS of V. cholerae $\mathrm{O} 1$ serotype Inaba bound to cholera toxin elicits vibriocidal antibodies against both Ogawa and Inaba serotypes $(2,3)$. The Ogawa and Inaba serotypes of $V$. cholerae $\mathrm{O} 1$ differ only by a 2-O-methyl group that is present in the non-reducing terminal sugar of the Ogawa $\mathrm{O}$-specific polysaccharide (O-SP) of the LPS, but is absent from the Inaba O-SP $(4,5,6)$. It is thus most likely that the protection induced in vaccine trials by Ogawa whole-cell vaccines is due to the induction of antibodies recognizing only this serotype-specific antigenic determinant. 
The new method in design of vaccines for Gram-negative bacteria is trough synthesis of glycoconjugates structures. The concept of the conjugates is linking the polysaccharides from bacteria with protein carrier. Immune response to conjugates with sugar ligand can be MHC-I/ T-dependent or T-independent (7). It is to be expected that T-dependent carbohydrate antigens with peptide carriers to induce T-dependant humoral immunity towards carbohydrate determinants. Development of glycoconjugate vaccines is expected to provide protection from other human bacterial pathogens with the utilization of capsular polysaccharides, LPS oligosaccharides and other carbohydrate determinants (8).

The new method in the synthesis, linkage and use of new protein carriers and better characterization of the conjugate vaccines will allow understanding of the mechanism of induction of immunity and will help in the rational design of high immunogenic and efficient vaccines.

\section{Study design}

The chosen model of design for synthesis of glycoconjugate immunogens is trough conjugation of carbohydrate component of bacterial lipopolysaccharide from Vibrio cholerae 01 serotype Inaba with two different protein carriers. This design should provide production of immunogenic molecule with carbohydrate antigen determinant and peptide hapten carrier. LPS as main bacterial antigen determinant with immunogenic characteristics will be used for synthesis of glycoconjugates. Because of the high toxicity of lipopolysaccharide molecule, detoxification for elimination of the toxic Lipid A is done with acetic and hydrazine hydrolysis of the LPS. The obtained oligosaccharides will still have immunogenic characteristics of the LPS $(9,10)$. For multiple points linkage between carbohydrate and protein molecule adipic acid derivatization is used (11). Bacterial B-subunit of cholera toxin (CT-B) and bovine serum albumin (BSA) are chosen as protein carriers. Cholera toxin is strong virulent determinant with antigenic characteristic, and with adjuvant properties in the conjugate. The use of B-subunit is because of its nontoxicity and adherent character. BSA is neutral antigen protein in the design concept of the glycoconjugates, and a hapten carrier (12).

The linker used for conjugation should provide separation of the two main glycoconjugate components, making them available for recognition and interaction with the elements of the immune system. With carboimide conjugation and use 1-etil-3, 3-dimetilaminopropil carboimid (EDC) this need is accomplished. EDC conjugation is very effective one step method for production of a large number of peptide-carrier immunogens (13).

\section{Experimental}

Materials. - Anhydrous hydrazine, adipic acid dihydrazide $(\mathrm{ADH})$; cianogenbromide $(\mathrm{CNBr})$; Cholera toxin B-subunit (CT-B) from $V$. cholerae 569B, biotype classical, serotype Inaba; LPS was of $V$. cholerae $\mathrm{O} 1569 \mathrm{~B}$, biotype classic, serotype Inaba, lot VC12-19, 1-Ethyl-3-(3-dimethylaminopropyl) carbodiimide (EDC) and agarose were from Sigma Chemical Co., St. Louis, Mo.; Sepharose CL-4B, Sephadex G-25 and G-50 were from Pharmacia AB, Uppsala, Sweden; bovine serum albumin (BSA) standard solution, Coomassie blue protein assay reagent, and triethylamine (TEA) were from Pierce, Rockford, Ill.; Limulus amebocyte lysate pyrogen was from BioWhittaker, Inc., Walkersville, Md.; Cellular cholera vaccine was obtained from Frank McCarthy, Wyeth-Ayerst Laboratories, Marietta, Pa.

Derivatisation of the protein carrier BSA. - Native BSA is with acid character (pI 4,5-5,1). For decreasing the acidity cationisation is done, which makes the protein molecule of BSA suitable for linkage with carbohydrate ligand (14). Cationisation is done with 1,8 $\mathrm{g}$ EDC on $5 \mathrm{~g}$ native BSA with addition of $350 \mathrm{ml}$ a.d. and mixed for 2 hours. The reaction is stopped with addition of $30 \mathrm{ml}$ acetic buffer. The product is dialyzed for 70 hours, lyophilised and named cationic BSA (cBSA). The protein carrier CT$B$ is used in its native form.

Detoxification of oligosaccharides. - LPS was detoxified by two methods. For acid hydrolysis $10 \mathrm{mg}$ of LPS was suspended in $10 \mathrm{ml}$ of $1 \%$ acetic acid, and was heated at 100 ${ }^{\circ} \mathrm{C}$ for $90 \mathrm{~min}$. The reaction mixture was ultracentrifuged $\left(60,000 \mathrm{rpm}, 10^{\circ} \mathrm{C}, 5 \mathrm{~h}\right)$, dialyzed against water and passed through a sterile 0.25 - $\mu \mathrm{m}$ pore-size membrane and freeze dried. The product was designated as O-SP and stored at $20^{\circ} \mathrm{C}$. For hydrazine hydrolysis, LPS $800 \mathrm{mg}$ was suspended in $80 \mathrm{ml}$ of anhydrous hydrazine and placed in a $37^{\circ} \mathrm{C}$ water bath for $2 \mathrm{~h}$ with stirring. The resultant precipitate was washed with cold $90 \%$ acetone, centrifuged $(35,000$ $\mathrm{rpm}, 10^{\circ} \mathrm{C}, 5 \mathrm{~h}$ ), and passed through a 2.5 - by 50 -cm column of G-50 Sephadex in pyrogen-free water; the void volume fractions were sterile filtered through a $0.25-\mu \mathrm{m}$ poresize membrane and freeze dried. The product was designated as deacylated LPS (DeA-LPS) and stored at $-20^{\circ} \mathrm{C}$.

Derivatisation of oligosaccharides. - O-SP and DeALPS $(10 \mathrm{mg} / \mathrm{ml})$ activated at $\mathrm{pH} 10.5$ with $\mathrm{CNBr}$ and bound to adipic acid dihydrazide (ADH) at $\mathrm{pH} 8.5$ were designated as O-SP-ADH and DeA-LPS-ADH, respectively. The extent of derivatization was determined by 2,4,6trinitrobenzene sulfonic acid assay (Pierce, Rockford, Ill.) using $\mathrm{ADH}$ as a standard. 
Conjugation of oligosaccharides with protein carriers. - cBSA or CT-B were mixed with OS-P-LPS-ADH and DeA-LPS-ADH in pyrogen-free saline in equal weight, and $450 \mathrm{mg}$ of 1-ethyl-3-3-dimethylaminopropyl carbodiimide was added. The reaction mixture was maintained at $\mathrm{pH} 5.5$ to 5.7 for $2 \mathrm{~h}$ and passed through a 2.5 - by $90-\mathrm{cm}$ column of G-50 Sephadex in $0.2 \mathrm{M} \mathrm{NaCl}-0.005 \mathrm{M}$ sodium phosphate ( $\mathrm{pH} 7.3)$. Fractions containing protein and polysaccharide were pooled, thimerosal was added to $0.01 \%$, and the preparations were sterile filtered and designated as $\mathrm{O}-\mathrm{SP}-\mathrm{cBSA}$ and $\mathrm{DeA}{ }_{\mathrm{LPS}}-\mathrm{cBSA}$ conjugates with cBSA as carrier, and O-SP-CT-B and DeA- ${ }_{\text {LPS }}-\mathrm{CT}-\mathrm{B}$ conjugates with CT-B as carrier, respectively.

\section{Determination of physical and chemical characteristics of conjugates}

Using electrophoretic separation with PAGE-SDS, glycoprotein detection of the carbohydrate parts of the conjugate and determination of the free unbound oligosaccharides with thin layer chromatography, characterization of the chemical and physical characteristics of the glycoconjugates was done.

SDS-PAGE analysis: LPS, oligosaccharides and synthesized conjugates (in concentration $50 \mathrm{mg}$ proteins per well) were analysed using polyacrylamide gel-electrophoresis in sodium-dodecyl sulfate (PAGE-SDS) on a 10-15\% running gel and a 4\% stacking gel (Bio-Rad). Conditions for PAGESDS were standard (start:100-200V $4{ }^{\circ} \mathrm{C}$, final:200-300V $12-14{ }^{\circ} \mathrm{C}$ ). Synthesized glycoconjugates after PAGE-SDS were visualized with two staining methods with different sensitivity and affinity to protein and carbohydrate components of the conjugates. Coomassie brilliant blue has high affinity and microgram detection to proteins but highly glucolised proteins are hard to be identified with this dye. Because of its sensitivity to carbohydrate fractions $(0,1 \mathrm{ng} / \mathrm{ml})$, a silver staining is done after the Coommassie brilliant blue (15) using Silver stain kit (Bio-Rad Labaratories).

Glycoprotein detection of the carbohydrate component in the synthesized glycoconjugates. - We have used biotin enzymatic reaction for detection of glycoproteins and visualization was done with streptavidin-alcaline phosphatase. Using dot-blot method, detection of the carbohydrate part of the glycoproteins is done (Immun-Blot Kit for glycoprotein detection, Bio-Rad Laboratories). The samples are immobilized an nitrocellulose membrane ( 20 $\mathrm{mg} / \mathrm{ml}$ per sample), the membrane is incubated with biothynilated solution, washed with PBS twice and treated with $5 \mathrm{ml}$ streptavidin alkaline phosphatase.

Determination of present impurity in synthesized glycoconjugates using thin layer chromatography. - TLC is used to detect the impurity from eventually present LPS or free unbound oligosaccharides of O-SP $\mathrm{LPS}_{\mathrm{LS}}$ and $\mathrm{De}_{\mathrm{LPS}}$ in the synthesized glycoconjugates through specific coloring with sulfuric acid. The samples in concentration of $50 \mathrm{mg} / \mathrm{ml}$ are immobilized on chromatographic plate (TLC silica gel plate $60 \mathrm{~F}_{254}, 20 \times 20 \mathrm{~cm}$ ), in mobile phase (ethanol/methanol). The plate is sprayed with "CHAR" (sulfuric acid solution) reagent and determination of the carbohydrate is in form of dark spots on the plate.

Bioassays The LPS concentration, assayed by the Limulus amebocyte lysate (LAL) assay done under standard procedure recommended by the kit manual (Bio-Whittaker), is expressed in endotoxin units relative to the US standard (16).

\section{Results and discussion}

\section{Chemical characterization of conjugates}

The extents of derivatization of O-SP and DeA-LPS with $\mathrm{ADH}$ are shown in Table 1.

The extent of derivatization of DeA-LPS and O-SP with $\mathrm{ADH}$ is very similar $(1,14 \%$ and $1,33 \%)$. The carbohydrate/protein ratio (wt/wt) ranges from 0,67 for O-SP-cBSA

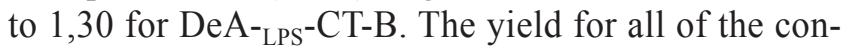
jugates was approximately $80 \%$, as calculated by the recovery of saccharides in the conjugates compared with the derivative polysaccharide. The results obtained from derivatization of oligosaccharides and determination of protein composition of the conjugates, suggested that satisfactory level of conjugation between oligosaccharides and proteins was accomplished.

Table 1. Characterization of V.cholerae O-SP and DeA-LPS protein conjugates

\begin{tabular}{|c|c|c|c|c|c|c|}
\hline \multirow[t]{2}{*}{ Conjugate } & \multirow{2}{*}{$\begin{array}{l}\mathrm{ADH} / \mathrm{OS}^{*} \\
(\mathrm{wt} / \mathrm{wt})\end{array}$} & \multirow{2}{*}{$\begin{array}{l}\mathrm{ADH} / \text { protein } \\
\text { (wt/wt) }\end{array}$} & \multirow{2}{*}{$\begin{array}{l}\text { OS/ protein } \\
\text { (wt/wt) }\end{array}$} & \multirow{2}{*}{$\begin{array}{l}\text { Yield } \\
(\%)\end{array}$} & \multicolumn{2}{|c|}{$\begin{array}{l}\text { Composition of the conjugates } \\
\qquad(\mathrm{mg} / \mathrm{ml})\end{array}$} \\
\hline & & & & & protein & OS \\
\hline O-SP-cBSA & 1,21 & 8,6 & 0,67 & 88 & 1,8 & 1,22 \\
\hline O-SP-CT-B & 1,14 & 7,8 & 0,60 & 75 & 1,0 & 0,55 \\
\hline $\mathrm{DeA}^{-{ }_{\mathrm{LPS}}}{ }^{-} \mathrm{cBSA}$ & 1,30 & 8,1 & 0,75 & 79 & 0,35 & 0,25 \\
\hline DeA- $_{\text {LPS }}-\mathrm{CT}-\mathrm{B}$ & 1,33 & 8,7 & 1,30 & 88 & 0,9 & 1,45 \\
\hline
\end{tabular}

* oligosaccharides (O-SP and DeA-LPS) 
Determination of the electrophoretical mobility of the synthesized glycoconjugates with polyacrilamide gel electrophoresis

Synthesized conjugates analyzed with reductive PAGESDS are stained with two different colors with different sensitivity and affinity towards protein and carbohydrate part of the glycoconjugates. Electrophoretic mobility of the conjugates are determinate corresponding to protein standard (SDS-PAGE Standard Broad range 6-200 kDa) and to CT-B, cBSA, O-SP ${ }_{\text {LPS }}$, DeA- ${ }_{\text {LPS }}$ and LPS.

\section{Coomassie Brilliant blue staining}

After Coomassie staining, the electrophoretic mobility was determinate for the following proteins and glycoproteins: protein carrier CT-B showed molecular weight of approximately $12 \mathrm{kDa}$, protein molecule of cBSA had 60 $\mathrm{kDa}$, conjugates with protein carrier of cBSA had molecular weight more than $60 \mathrm{kDa}$, while conjugates with protein CT-B had molecular weight of $12 \mathrm{kDa}$.

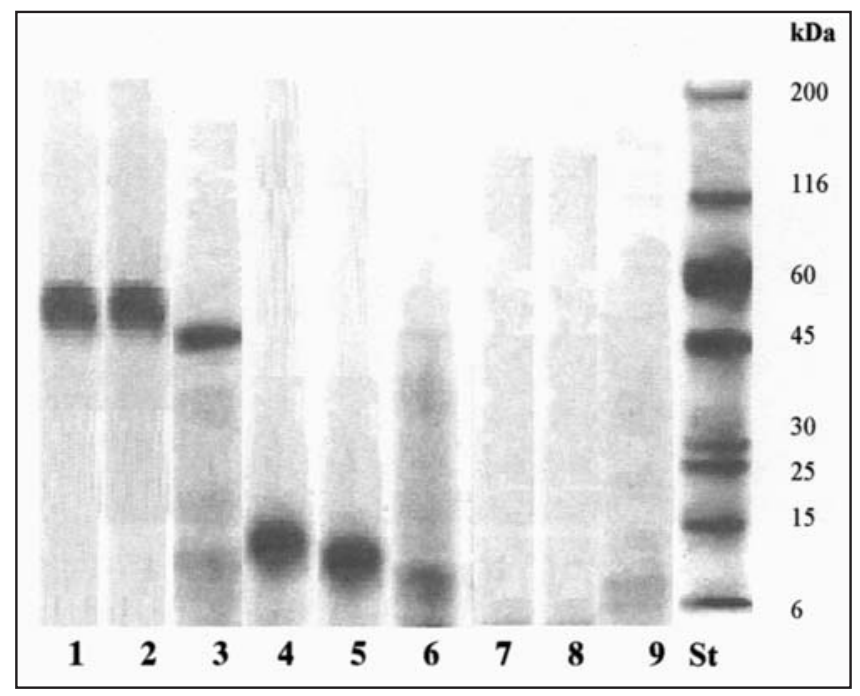

Fig.1 Comassie brilliant blue staining of SDS-PAGE gel

1. DeA-LPS-cBSA; 2. O-SP- LPS -cBSA; 3. cBSA;

4. DeA-LPS-CT-B; 5. O-SP-LPS-CT-B; 6. CT-B; 7. O-SP;

8. DeA-LPS 9. LPS

Samples from O-SP, DeA $A_{\text {LPS }}$ and LPS did not show signal, because of selective staining only of the proteins with Coomassie brilliant blue. The carbohydrates present in the glycoconjugates are decreasing the mobility of the conjugates due to the increasing of molecular weight of 1,5-2 kDa, which is difficult to detect in respect to unbound cBSA and CT-B.

\section{Silver staining}

Using this staining method after the Coomassie stain, except for the bands of $\sim 12 \mathrm{kDa}$ (DeA- ${ }_{\mathrm{LPS}}-\mathrm{CT}-\mathrm{B}$ and O-SP${ }_{\text {LPS }}-\mathrm{CT}-\mathrm{B}$ ) and $\sim 60 \mathrm{kDa}$ (DeA- ${ }_{\text {LPS }}{ }^{-\mathrm{CBSA}}$ and $\mathrm{O}-\mathrm{SP}{ }_{\text {LPS }}-\mathrm{cBSA}$ ) of the synthesized conjugates, the bands from oligosaccharides and LPS are also detected. O-SP had molecular weight of $6 \mathrm{kDa}, \mathrm{DeA}_{\mathrm{LPS}}$ of $\sim 8 \mathrm{kDa}$ and LPS of $\sim 13 \mathrm{kDa}$.

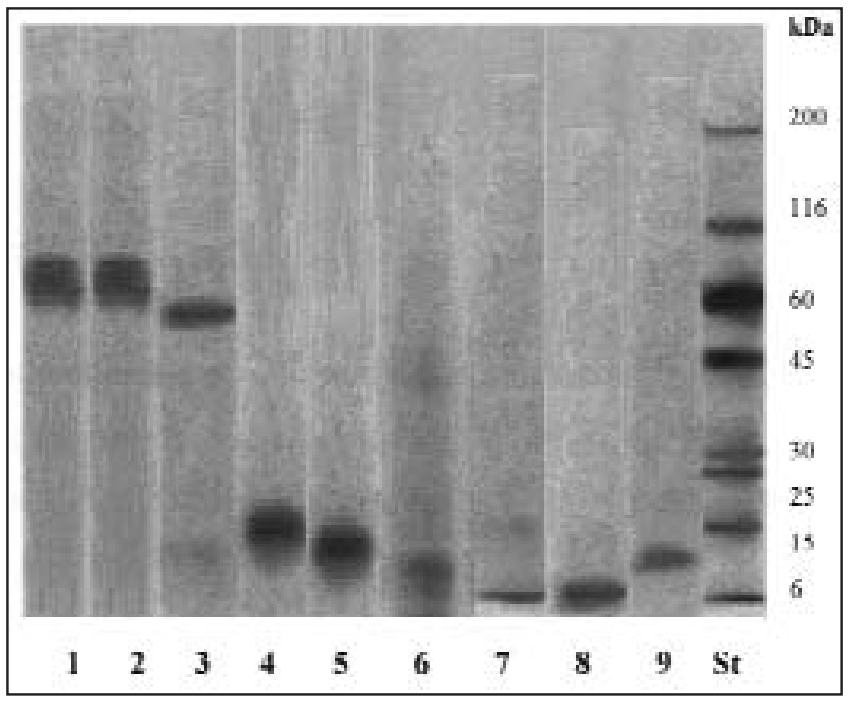

Fig. 2 Silver staining of SDS-PAGE gel 1. DeA-LPS-cBSA; 2. O-SP-LPS-cBSA; 3. cBSA; 4. DeA-LPS-CT-B;

5. O-SP-LPS-CT-B; 6. CT-B; 7. OS-P; 8. DeALPS ; 9.LPS

Glycoprotein detection of the carbohydrate component in the synthesized glycoconjugates

Glycoprotein detection of the carbohydrate component in the synthesized glycoconjugates is done using dot-blot immobilization of the samples on nitrocellulose membrane. The samples are applied in duplicates in concentration of $20 \mathrm{mg} / \mathrm{ml}$. Protein carriers CT-B and cBSA are used as negative control, and LPS, O-SP and DeA- ${ }_{\text {LPS }}$ as positive control.

Positive signal is detected in all conjugates and in carbohydrate components LPS, O-SP and DeA- ${ }_{\text {LPS }}$, while protein controls from cBSA and CT-B did not show signal. The positive signal in synthesized glycoconjugates is confirmation of the conjugation between carbohydrate and protein components in the conjugates.

Determination of present impurity in synthesized glycoconjugates

Using TLC and specific "CHAR" reagent, the eventually present impurity from present LPS or free unbound oligosaccharides of $\mathrm{O}-\mathrm{SP}_{\mathrm{LPS}}$ and $\mathrm{DeA}_{\mathrm{LPS}}$ in the synthesized glycoconjugates is detected. LPS, $\mathrm{O}-\mathrm{SP}_{-}{ }_{\text {LPS }}$ and $\mathrm{DeA}{ }_{-}{ }_{\text {LPS }}$ are identified on the starting place of application and are not mobile in the used mobile phase. In all conjugates the carbohydrate component is detected, but single bands from LPS, O-SP- $-_{\text {LPS }}$ and $\mathrm{DeA}_{\mathrm{LPS}}$ are not present which points to high purity of the synthesized glycoproteins. 


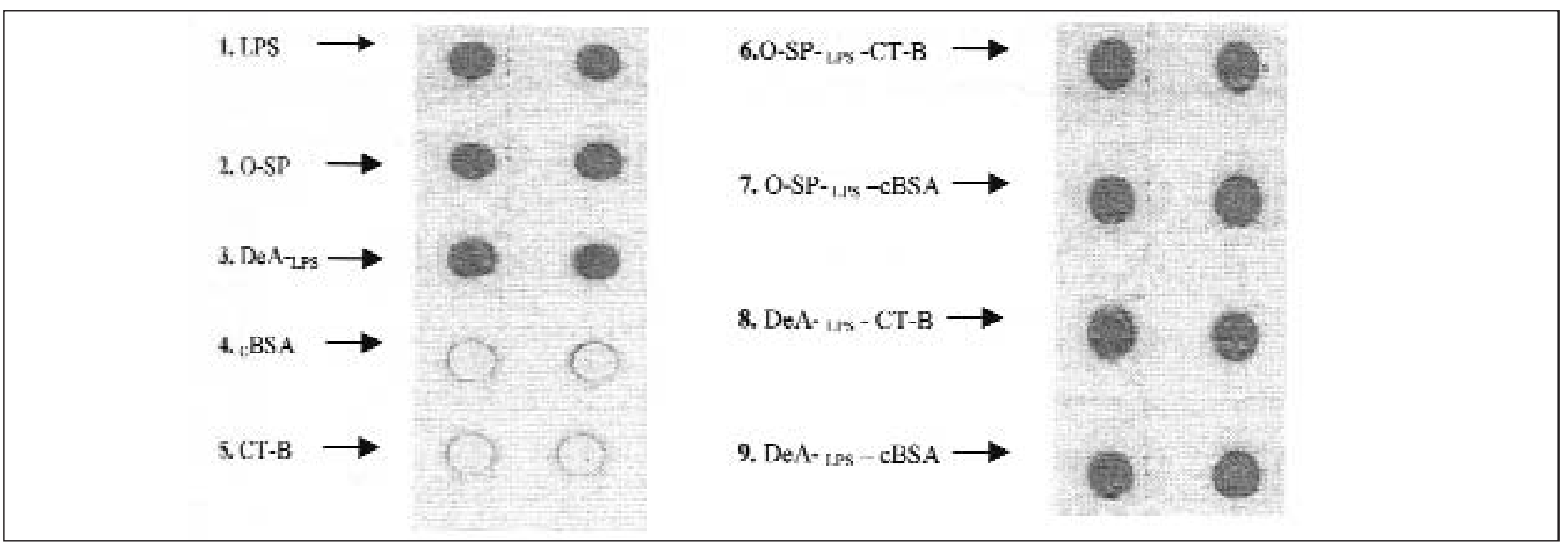

Fig. 3 Dot-blot analysis in duplicates of the synthesized glucoconjugates and their protein and carbohydrate components 1. LPS; 2. O-SP ; 3. DeA- LPS; 4. CBSA; 5. CT-B; 6. O-SP- LPS -CT-B; 7. O-SP- LPS -cBSA; 8. DeA- LPS - CT-B ; 9. DeA- LPS - cBSA

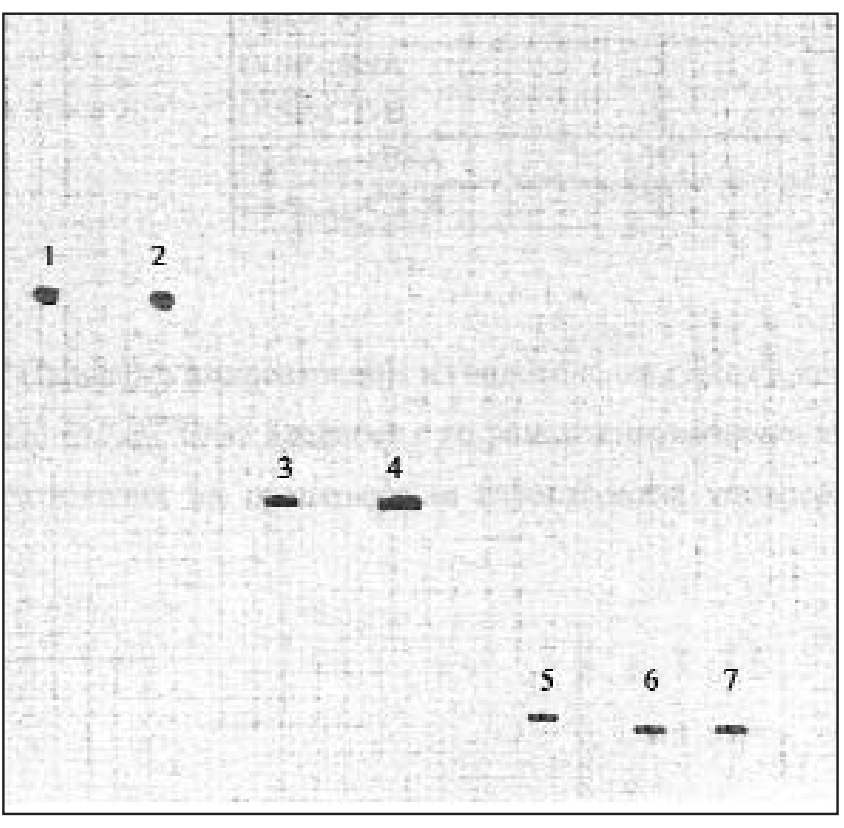

Fig. 4. TLC profile of the synthesized glycoconjugates

1. DeA-LPS-CT-B; 2. O-SP- LPS -CT-B;

3. DeA-LPS- cBSA; 4. O-SP-LPS- cBSA; 5. LPS;

6. OS-P; 7. DeA-LPS

Table 2. Concentration of endotoxins (EU/mg) in the synthesized conjugates

\begin{tabular}{lc}
\hline \hline Immunogen & $\begin{array}{c}\text { Concentration of } \\
\text { Endotoxins }(\mathrm{EU} / \mu \mathrm{g})\end{array}$ \\
\hline O-SP & 2 \\
DeA-LPS & 3 \\
O-SP-cBSA & 5 \\
O-SP-CT-B & 5 \\
DeA-LPS-CBSA & 10 \\
DeA-LPS-CT-B & 20 \\
\hline
\end{tabular}

Determination of the concentration of the endotoxins present in the synthesized glycoconjugates

Concentration of bacterial endotoxins is determined in all synthesized conjugates and oligosaccharides. The conjugate DeA- ${ }_{\text {LPS }}$-CT-B had a higher endotoxin level (20 $\mathrm{EU} / \mathrm{mg}$ ). This value is in the rang of the approved concentration for parenteral preparations for human use (16).

Vaccines are the most cost-effective way of preventing and controlling infectious diseases caused by microorganisms. The success of the Hib conjugate vaccine and promising results obtained from clinical trials of meningococcal and pneumococcal vaccines have assured an exciting future for glycoconjugate vaccines. Glycoconjugates can be prepared, using a variety of coupling strategies, from surface carbohydrates such as capsular polysaccharides, lipopolysaccharides from bacteria or synthetic saccharides. Progress will be made in the development of novel vaccines to protect against a wide variety of other human and animal bacterial pathogens based on surface carbohydrates such as capsular polysaccharides, LPS saccharides and less common saccharides.

\section{Conclusions}

We have synthesized glycoconjugates composed of carbohydrate component from oligosaccharide specific polysaccharide and deacetyled lipopolysaccharide of Vibrio cholerae 01 serotype Inaba and protein carrier cationic bovine serum albumin and B-subunit of cholera toxin. The synthesized glycoconjugates DeA $\mathrm{LPS}_{\mathrm{L}}-\mathrm{CT}-\mathrm{B}, \mathrm{O}-\mathrm{SP}-\mathrm{CT}-\mathrm{B}$, De $\mathrm{A}_{\mathrm{LPS}}-\mathrm{cBSA}$ and O-SP-cBSA have been analyzed with glycoprotein detection method, and conjugation between the carbohydrate and protein part in the glycoconjugates is conferred. The presents of impurity from the free unbound oligosaccharides and lipopolysaccharides in the synthe- 
sized glycoconjugates were not detected using TLC analysis. Electrophoretic separation and determination of the molecular weight of glycoconjugates was done using SDS-PAGE and two different staining. Concentration of bacterial endotoxins in all synthesized conjugates and oligosaccharides is determined using LAL test. Low level of endotoxin concentration found in all conjugates is proof that synthesized glycoconjugates are safe and can be used for future immunization of experimental animals. The advances in synthetic methodology, coupling technology, introduction of novel carrier proteins and better characterization of conjugate vaccines will permit greater understanding of the mechanisms by which these vaccines induce protective responses and facilitate the rational design of highly immunogenic and protective vaccines.

\section{References}

1. U.H. Stroeher, L. E. Karageorgos, R. Morona and P. A. Manning, Proc. Natl. Acad. Sci. USA, 89, 2566-2570 (1992).

2. R. K. Gupta, S. C. Szu, R. A. Finkelstein and J. B. Robbins. Infect. Immun., 60, 3201-3208 (1992).

3. R. K. Gupta, D. N. Taylor, D. A. Bryla, J. B. Robbins and S. S. C. Szu. Infect. Immun., 66, 3095-3099 (1998).

4. K. Hisatsune, S. Kondo, Y. Isshiki, T. Iguchi and Y. Haishima Biochem. Biophys. Res. Commun., 190, 302-307 (1993).

5. T. Ito, T. Higuchi, M. Hirobe, K. Hiramatsu and T. Yokota, Carbohydr. Res., 256, 113-128 (1994).
6. D. Wang and E. Kabat. Carbohydrate antigens (polysaccharides), In Structure of antigens, vol. 3. M. H. V. Van Regenmortel (ed.), CRC Press, New York, N.Y., 1996 pp. 247-276

7. M. L. Levine, N. F. Pierce, Immunity and vaccine development in Cholera, D. Barua and W. B. Greenough, “ ed. III. New York: Plenum, 1992, pp. 285-327

8. Z. Kossaczka, J. Shiloach, V. Johnson, D. N. Taylor, R. A. Finkelstein, J. B. Robbins and S. C. Szu. Infect. Immun., 68, 5037-5043 (2000).

9. I. J. Goldstein, G. W. Hay, B. A. Lewis and F. Smith, Methods Carbohydr. Chem. 5, 361-370 (1970).

10. O. Westphal and K. Jann, Methods Carbohydr. Chem., 5, 83-87 (1965).

11. C. Y. Chu, B. K. Liu, D. Watson, S. S. Szu, D. Bryla, J. Shiloach, R. Schneerson, and J. B. Robbins. Infect. Immun., 59, 4450-4458 (1991).

12. S. C. Szu, R. Gupta and J. B. Robbins. In Vibrio cholerae and cholera, I. K. Wachsmuth, P. A. Blake, and O. Olsvik (ed.), American Society for Microbiology, Washington, D.C. 1994, pp. 381-394.

13. L. Moroder, Biol. Chem., 369, 381-385 (1988).

14. D. L. McDonalds, J. Lipid. Res., 21, 642-645 (1980)

15. C. M. Tsai and C. E. Frasch. Anal. Biochem., 119, 115-119 (1982).

16. H. D. Hochstein, Role of the FDA in regulating the Limulus amoebocyte lysate test. In R. B. Prior (ed.), Clinical applications of the Limulus amoebocyte lysate test. CRC Press, Boca Raton, Fla, 1990, pp. 38-49

\title{
Резиме
}

\section{Дизајнирање, синтеза и определување на физичко-хемиските карактеристики на гликоконјугатни структури како модел на олигосахаридни вакцини на Vibrio Cholerae}

\author{
Грозданова Александра*, Поцева Ана, Миленкова Катерина, Шутуркова Љубица

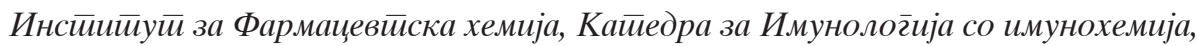 \\ Универзииеей “Св. Кирил и Мейодиј”, Водњанска 17, 1000 Скойје, Македонија
}

Клучни зборови: вакцини, гликоконјугати, Vibrio cholerae,LPS, колера токсин

Колерата е токсин посредувана ентероинфекција, со епидемични размери и со приближно 120000 смртни случаи годишно во светската популација. Заштита од колера не е постигната заради ограничувањата на достапните вакцини. Користејќи сознанија од литературата (Robbins JB. 1990; Ogawa Y, 1996) синтетизиравме гликоконјугатни имуногени со шеќерна компонента од детоксициран LPS од Vibrio cholerae и протеински носачи. Конјугатите беа припремени преку врзување на липополисахаридот од Vibrio cholerae O1, серотип Inaba третиран со кисела и хидразинска хидролиза (O-SP and DeALPS) и колера токсин Б-субединица (СТ-В) и говедскиот серум албумин (cBSA). Дихразидот од адипинска киселина беше користен за дериватизација на олигосахаридите, а како конјугирачко средство го користевме 1-ethil-3-(3-dimethilaminopropil) carbodiimide (EDC). Со редуктивна SDSPAGE, гликопротеинска детекција и TLC дот-блот анализа извршено е физичко-хемиско профилирање на добиените конјугати. Безбедна концентрација на ендотоксини беше утврдено кај сите конјугати, користелќи LAL тест. Вака синтетизираните гликоконјугати може да се користат за следни имунизации на експериментални животни. Се очекува конјугатните вакцини да се сигурни и ефикасни и да покажат висока имуно геност и Т-клеточно зависни својства обезбедувајќи долготраен заштитен имунитет кон колерата и можност за разјаснување на механизмот за појава на болеста. 